\title{
P210 breakpoint is associated with less minimal residual disease compared to p190 breakpoint in acute lymphoblastic leukemia patients with Philadelphia chromosome
}

\author{
Philadelphia kromozomu olan akut lenfoblastik lösemi hastalarında p210 kırılma \\ noktası P190 kırılma noktasına göre daha az minimal kalıntı hastalığı ile ilişkilidir
}

\author{
(D) Tuğçe Nur Yiğenoğlu'1, (1) Taha Bahsi², (1) Haktan Bağış Erdem², () Neslihan Düzkale, \\ (D) Bahar Uncu Ulu ${ }^{1}$, () Dicle İskender ${ }^{1}$, () Merih Kızıl Çakar ${ }^{1}$, (1) Mehmet Sinan Dal ${ }^{1}$, (1) Fevzi Altuntas ${ }^{1}$
}

${ }^{1}$ University of Health Sciences, Ankara Dr. Abdurrahman Yurtaslan Oncology Training and Research Hospital, Department of Hematology and Bone Marrow Transplantation Center, Ankara, Turkey

${ }^{2}$ University of Health Sciences, Ankara Dr. Abdurrahman Yurtaslan Oncology Training and Research Hospital, Department of Genetics, Ankara, Turkey

${ }^{3}$ University of Health Sciences, Ankara Dışkapı Yıldırım Beyazıt Training and Research Hospital, Department of Genetics, Ankara, Turkey

Cite this article as / Bu makaleye atıf için: Yiğenoğlu TN, Bahsi T, Erdem HB, et al. P210 breakpoint is associated with less minimal residual disease compared to p190 breakpoint in acute lymphoblastic leukemia patients with Philadelphia chromosome. J Health Sci Med 2020; 3(3): 307-311.

\begin{abstract}
Introduction: The Philadelphia chromosome is the most common cytogenetic abnormality in adult patients with acute lymphoblastic leukemia. In addition to its role in treatment choice, evaluation of Philadelphia chromosome is also important to monitor the minimal residual disease. In this study, we aim to study the differences of minimal residual disease status between 2 breakpoint regions (p190 and p210) in adult patients with acute lymphoblastic leukemia.

Material and Method: The data of 205 acute lymphoblastic leukemia patients whose genetic evaluations were performed at our center between March 2010 and February 2019 were retrospectively analyzed.

Results: Philadelphia chromosome was observed in 30 (14.6\%) patients. In $75 \%$ of the patients who had p 210 breakpoint at the time of diagnosis, minimal residual disease was negative after 2 cycles of chemotherapy whereas only $42.8 \%$ of the patients who had p190 at the time of diagnosis, minimal residual disease was negative after 2 cycles of chemotherapy. The frequency of Philadelphia chromosome was the highest in 51-60 years age group and it was the least in 18-39 age group in adult B cell acute lymphoblastic leukemia patients.

Conclusion: To the best of our knowledge, this is the first study which evaluated the minimal residual disease status of Philadelphia positive acute lymphoblastic leukemia patients by classifying them into 2 groups according to 2 breakpoints (p190 and p210) in the BCR locus. In our study, we found that p190 breakpoint is associated with less minimal residual disease negative status compared to the patients with p210 breakpoint, therefore more augmented therapies may be preferred in patients with p190 breakpoint compared to therapies of patients with p210 breakpoint.
\end{abstract}

Keywords: Philadelphia chromosome, minimal residual disease, p210 breakpoint, p190 breakpoint

ÖZ

Giriș: Philadelphia kromozomu, akut lenfoblastik lösemili erișkin hastalarda en sık görülen sitogenetik anormalliktir. Philadelphia kromozomunun değerlendirilmesi, tedavi seçimindeki rolüne ek olarak minimal rezidüel hastalığı izlemek için önemlidir. Bu çalışmada akut lenfoblastik lösemili yetişkin hastalarda 2 kırılma noktası (p190 ve p210) arasındaki minimal rezidüel hastalığı durumu farklılıklarını araştırmayı amaçladık.

Gereç ve Yöntem: Mart 2010-Şubat 2019 tarihleri arasında merkezimizde genetik tetkikleri yapılan 205 akut lenfoblastik lösemili hastasının verileri retrospektif olarak incelendi.

Bulgular: 30 hastada (\%14,6) Philadelphia kromozomu gözlendi. Tanı anında p210 kırılma noktası olan hastaların \%75'inde 2 siklus kemoterapi sonrasında minimal rezidüel hastalığı negatif hale gelirken, tanı anında p190 kırılma noktası olan hastaların sadece \%42,8'inde 2 siklus kemoterapi sonrasında minimal rezidüel hastalığı negatif hale geldi. Philadelphia kromozomu siklığ $151-60$ yaş grubunda en yüksek, 18-39 yaş grubunda en az idi.

Sonuç: Literatür taramamıza göre bu çalıșma, Philadelphia pozitif akut lenfoblastik lösemili hastalarının minimal rezidüel hastalığ durumunu kırılma noktalarına göre (p190 ve p210) 2 gruba ayırarak değerlendiren ilk çalışmadır. Çalışmamızda BCR lokusundaki p190 kırılma noktasının, p210 kırılma noktasına sahip hastalara kıyasla daha az minimal rezidüel hastalığı negatif durum ile ilişkili olduğunu bulduk, bu nedenle p190 kırılma noktası olan hastalarda p210 kırılma noktası olan hastalarda kullanılan tedavilere kıyasla daha fazla yoğun tedaviler tercih edilebilir.

Anahtar Kelimeler: Philadelphia kromozomu, minimal rezidüel hastalık, p210 kırılma noktası, p190 kırılma noktası 


\section{INTRODUCTION}

Acute lymphoblastic leukemia (ALL) is a hematological malignancy characterized by abnormal proliferation of lymphoblasts and can be originated from B-cell lineage (B-ALL) or less commonly T-cell lineage (T-ALL). ALL is a heterogeneous disease that has different morphologic, cytogenetic, and molecular subgroups and becomes symptomatic in a short time due to its aggressive nature (1-3). ALL is the most common childhood malignancy, represents about $80 \%$ of all childhood leukemias; but only about $20 \%$ of adult leukemias. It has a bimodal distribution that has a peak at $4-5$ years and 50 years. The incidence is up to $5 / 100,000$ in children and $2 / 100,000$ in adults (4). Diagnosis of ALL depends on the evaluation of morphology, flow cytometry, immunophenotyping, identification of cytogenetic and molecular abnormalities (4).

The pathogenesis of ALL patients involves a complex chain of events that block the proliferation and differentiation of lymphoid precursor cells and drive aberrant cell proliferation and survival. Improvements in the field of genetic revealed that several changes in the genome are required for leukemogenesis $(4,5)$. The characterization of these genetic alterations that required for leukemogenesis has allowed the identification of the genes critical for pathogenesis and prognosis of ALL (6-8). Wiemels et al. (9) showed that there were chromosomal translocations and rearrangements of the TELAML1 fusion gene in neonatal blood cells of identical twin children with ALL, even several years before the onset of the disease and this may be the earliest evidence about the relation between genetic alterations and ALL pathogenesis. Currently, in more than $80 \%$ of ALL patients, numerical and structural chromosomal abnormalities can be identified due to the advances in conventional and molecular methods $(5,10$ 12).

The evaluation of genetic alterations is crucial for diagnosis, risk classification and treatment choice (13). World Health Organization (WHO) classification of hematopoietic neoplasms, the category "B lymphoblastic leukemia/lymphoma with recurrent genetic abnormalities" has 7 recurrent genetic abnormalities including $\mathrm{t}(9 ; 22)$ (q34.1;q11.2), BCR-ABL1; $\mathrm{t}(\mathrm{v} ; 11 \mathrm{q} 23.3)$, KMT2A rearranged; $\mathrm{t}(12 ; 21)$ (p13.2; 22.1$)$, ETV6RUNX1; hyperdiploidy; hypodiploidy; $\mathrm{t}(5 ; 14)$ (q31.1;q32.3), IL3-IGH; t(1;19) (q23;p13.3); TCF3-PBX1 and 2 provisional entities including BCR-ABL1-like and iAMP21 s14.

The Philadelphia $(\mathrm{Ph})$ chromosome is the most common cytogenetic abnormality in adult patients with ALL and the incidence increases with age. It is observed in $3 \%$ of childhood ALL cases and up to 50\% of ALL patients at the age of 50 years and older (15-20). Ph chromosome results from a reciprocal translocation between the Abelson (ABL-1) oncogene on the long arm of chromosome 9 and a breakpoint cluster region (BCR) on the long arm of chromosome 22. Because of this translocation, BCR gene is joined to the $\mathrm{ABL}$ oncogene and forms $\mathrm{BCR}-\mathrm{ABL}$ fusion gene. This fusion gene encodes an oncogenic protein with constitutively active tyrosine kinase activity that interacts with RAS, AKT, and JAK/STAT pathways and contributes to proliferation and tumor growth (21-23). In adult ALL patients with Ph chromosome, approximately $25 \%$ have a 210 breakpoint and $75 \%$ have a p190 breakpoint in the BCR locus (23).

$\mathrm{Ph}$ positive ALL has a high risk for relapse and central nervous system (CNS) involvement, patients typically present with an aggressive clinical course. Historically, patients with $\mathrm{Ph}$ positive ALL had an inferior outcome when compared to the patients with Ph negative ALL but the prognosis of $\mathrm{Ph}$ positive ALL patients had changed after the introduction of tyrosine kinase inhibitors (TKIs) into clinical practice $(24,25)$. Therefore, evaluation of $\mathrm{Ph}$ chromosome at the time of diagnosis is very important since it has an important role in the treatment choice. In addition to its role in treatment choice, evaluation of $\mathrm{Ph}$ chromosome is also important to monitor the disease status and minimal residual disease (MRD). MRD monitoring is crucial for early relapse estimation and treatment decisions. Previous studies revealed that 2 breakpoint regions may be associated with different clinical phenotypes in adult ALL patients (26). In this study, we aimed to investigate the differences of MRD status between 2 breakpoint regions (p190 and p210) in adult patients with $\mathrm{Ph}$ positive ALL.

\section{MATERIAL AND METHOD}

The data of 205 ALL patients whose genetic evaluations were performed at our center between March 2010 and February 2019 were retrospectively analyzed. This study was approved by the university /local human research ethics committee and all procedures performed in studies involving human participants were in accordance with the ethical standards of the institutional and/or national research committee and with the 1964 Helsinki Declaration and its later amendments or comparable ethical standards. The study was carried out with the permission of Ethics Committee of Dr. Abdurrahman Yurtaslan Ankara Oncology Training and Research Hospital (Permission granted /Decision number: 04.12.2019/475). 
Patients aged between 18-40 years, received Danafarber chemotherapy protocol, those aged between 41-55 years received HyperCVAD chemotherapy protocol and those at the age of 56 and older and had good performance status received Ewall chemotherapy protocol whereas patients with poor performance status received vincristine and dexamethazone. Performance status was evaluated with Eastern Cooperative Oncology Group (ECOG) and Charlson Comorbidity Index (CCI). Good performance status was accepted as ECOG:0-2 or CCI:12 whereas poor performance status was accepted as ECOG:3-4 or CCI $>2$. MRD status was evaluated after 2 cycles of chemotherapy. 4 log reduction of abnormal transcript number after induction therapy was accepted as MRD negative.

Written informed consent was obtained from all patients before testing for the use of their ribonucleic acid (RNA) samples for research purposes. Total RNA from ethylenediaminetetraacetic acid (EDTA) -anticoagulated peripheral blood was extracted with an RNA extraction kit (QIAamp RNA Blood Mini Kit). RNA was reverse transcribed with an Ipsogen ${ }^{\circ}$ RT Kit. cDNA was stored at $-20{ }^{\circ} \mathrm{C}$. BCR-ABL1 cDNA was performed on Qiagene Rotor-Gene-Q with TaqMan probes, according to manufacturer's instructions. Each Ipsogen BCR-ABL1 $\mathrm{Mbcr}$ Kit provides four standard dilutions for ABL and five standard dilutions for Mbcr. Use of the Ipsogen BCRABL1 Mbcr kits enables detection and quantification of BCR-ABL1 and ABL transcripts. The reaction was initiated according to the optimized protocols defined by the manufacturer.

The statistical analyses were performed with SPSS V21.0 (SPSS Inc., Chicago, IL) software. Descriptive statistics were used to summarize the data.

\section{RESULTS}

Two hundred five patients with B cell ALL were included in the study. Ph chromosome was observed in 30 (14.6\%) patients. In adult ALL patients with $\mathrm{Ph}$ chromosome $14(53.3 \%)$ had p210 breakpoint and $16(46.7 \%)$ had p190 breakpoint in the BCR locus. There was not any patients who had both p190 and p210 breakpoints. Median age of the patients with $\mathrm{Ph}$ chromosome was 56. The characteristics of the patients with Ph positive ALL is given in Table 1 . The frequency of $\mathrm{Ph}$ chromosome was the highest in 51-60 years age group and it was the least in 18-39 age group in adult B cell ALL patients. The frequency of $\mathrm{Ph}$ chromosome according to the age groups is given in Table 2 . In $75 \%$ of the patients who had p210 at the time of diagnosis, MRD was negative after 2 cycles of chemotherapy whereas only $42.8 \%$ of the patients who had p190 at the time of diagnosis, MRD was negative after 2 cycles of chemotherapy.

\begin{tabular}{|lccc|}
\hline \multicolumn{4}{|c|}{ Table 1. The characteristics of patients with Ph positive ALL } \\
\hline & $\begin{array}{c}\text { p210 } \\
\text { positive }\end{array}$ & $\begin{array}{c}\text { p190 } \\
\text { positive }\end{array}$ & $\begin{array}{c}\text { Ph } \\
\text { Chromosome }\end{array}$ \\
\hline $\mathrm{n}$ & 16 & 14 & 30 \\
\hline Gender & $\begin{array}{c}7 \text { female } \\
9 \text { male }\end{array}$ & $\begin{array}{c}7 \text { female } \\
\text { male }\end{array}$ & 14 female \\
\hline Median age & $\begin{array}{c}55 \\
\text { (range 18-66) }\end{array}$ & $\begin{array}{c}\text { (range 18-76) } \\
\text { (range 18-76) }\end{array}$ \\
\hline
\end{tabular}

Ph Chromosome: Philadelphia Chromosome

\begin{tabular}{|lcccc|}
\hline \multicolumn{4}{|l|}{ Table 2. The frequency of Ph chromosome according to age groups } \\
\hline Age group & $\mathbf{n}$ & $\begin{array}{c}\text { p210 } \\
\text { positive }\end{array}$ & $\begin{array}{c}\text { p190 } \\
\text { positive }\end{array}$ & $\begin{array}{c}\text { Ph } \\
\text { Chromosome }\end{array}$ \\
\hline $18-39$ & 96 & 4 & 5 & $9(9.3 \%)$ \\
$40-50$ & 39 & 3 & 2 & $5(12.8 \%)$ \\
$51-60$ & 38 & 6 & 5 & $11(28.9 \%)$ \\
$>60$ & 32 & 3 & 2 & $5(15.6 \%)$ \\
$\geq 18$ & 205 & 16 & 14 & $30(14.6 \%)$ \\
\hline Ph Chromosome: Philadelphia Chromosome & \\
\hline \multicolumn{5}{|l}{} \\
\hline
\end{tabular}

\section{DISCUSSION}

ALL arises from recurrent genetic alterations that block precursor $\mathrm{B}$ and $\mathrm{T}$ cell differentiation (22). The etiology of ALL has been under investigation for decades but the exact cause is still unknown (27). Genetic alterations are observed in approximately $75 \%$ of patients with ALL (20). These genetic alterations influence the prognosis and therapeutic approach (20). ALL has a mean survival of $35 \%$ in patients aged between 18 and 60 years (28). Because of this poor survival, markers that can be translated to therapeutic targets are very important (29). Nowell and Hungerford (30) described the translocation between chromosomes 9 and 22 leading to the short chromosome 22. Observation of the role of BCR-ABL fusion gene in the leukemogenesis led to the development of a number of TKIs for the treatment of $\mathrm{Ph}$ positive B-ALL (31).

In the study conducted by Bartram et al. (3) $\mathrm{Ph}$ chromosome was found in $25 \%$ of adult ALL patients and up to $50 \%$ in older ALL patients. In the study conducted by Azevedo et al. (32) Ph chromosome was found in 34\% of Brazilian adult patients with ALL. Gleier et al. (24) showed that $37 \%$ of 478 adult ALL patients had BCR-ABL fusion gene. In our study, $\mathrm{Ph}$ chromosome was found in $14.6 \%$ of adult ALL patients and $15.6 \%$ of B ALL patients over 60 years.

The prevalence of genetic alterations varies according to age groups (13). In our study, we observed that $\mathrm{Ph}$ chromosome was most common in 51-60 years age group (28.9\%) and was observed only in $9.3 \%$ of ALL patients in 18-39 years age group. 
Nashed et al. (23) observed that in adult ALL patients with $\mathrm{Ph}$ chromosome, approximately $25 \%$ had p210 breakpoint and $75 \%$ had a p190 breakpoint in the BCR locus. In the study conducted by Gleier et al. (24) in patients with $\mathrm{Ph}$ chromosome, $77 \%$ had p190 breakpoint, $20 \%$ had p210 breakpoint and 3\% had both isoforms. Dombret et al. (33) found that in patients with $\mathrm{Ph}$ chromosome, $68 \%$ had p190 breakpoint, $28 \%$ had p 210 breakpoint and $4 \%$ had both isoforms. In our study, in adult ALL patients with $\mathrm{Ph}$ chromosome 53.3\% had p210 breakpoint and $46.7 \%$ had p190 breakpoint in the BCR locus. There was not any patients who had both p190 and p210 breakpoints.

MRD monitoring is very important for both pediatric and adult ALL (5). In our study, in $75 \%$ of patients who had p210 breakpoint in the BCR locus at the time of diagnosis, p210 breakpoint could not be detected after 2 cycles of treatment. In $42.8 \%$ of patients who had p190 breakpoint in the BCR locus at the time of diagnosis, p190 could not be detected after 2 cycles of treatment.

\section{CONCLUSION}

In conclusion, genetic evaluation of ALL patients is very important to plan treatment approaches. Ph chromosome can be observed in up to $1 / 3$ of patients in 51-60 years age group. There is quite limited data about MRD evaluations in ALL patients with $\mathrm{Ph}$ chromosome and to our knowledge this is the first study which evaluated the MRD status of $\mathrm{Ph}$ positive ALL patients by classifying them into 2 groups according to 2 isoforms (p190 and p210). In our study, we found that p190 breakpoint is associated with less MRD negative status compared to the patients with p210 breakpoint in the BCR locus. As p190 breakpoint is associated with less MRD negative status compared to the patients with p210 breakpoint in the BCR locus, more augmented therapies may be preferred in patients with p190 breakpoint compared to therapies of patients with p210 breakpoint. Further prospective, randomized studies are needed about the relation between MRD status and $\mathrm{Ph}$ chromosome isoforms.

Abbreviations: ABL: Abelson; ALL: Acute lymphoblastic leukemia; BCR: Breakpoint cluster region; CNS: Central nervous system; EDTA: Ethylenediaminetetraacetic acid; MRD: Minimal residual disease; Ph: Philadelphia; RNA: Ribonucleic acid; TKI: Tyrosine kinase inhibitor; WHO: World Health Organization.

\section{ETHICAL DECLARATIONS}

Ethics Committee Approval: The study was carried out with the permission of Ethics Committee of Dr. Abdurrahman Yurtaslan Ankara Oncology Training and Research Hospital (Permission granted: 04.12.2019, Decision number: 475).

Informed Consent: Because the study was designed retrospectively, no written informed consent form was obtained from patients.

Referee Evaluation Process: Externally peer-reviewed.

Conflict of Interest Statement: The authors have no conflicts of interest to declare.

Financial Disclosure: The authors declared that this study has received no financial support.

Author Contributions: All of the authors declare that they have all participated in the design, execution, and analysis of the paper, and that they have approved the final version.

\section{REFERENCES}

1. Fey MF, Buske C. Acute myeloblastic leukaemias in adult patients: ESMO Clinical Practice Guidelines for diagnosis, treatment and follow-up. Ann Oncol 2013; 24: vi138-43.

2. De Kouchkovsky I, Abdul-Hay M. Acute myeloid leukemia: a comprehensive review and 2016 update. Blood Cancer J 2016; 6: e441.

3. Bartram CR, de Klein A, Hagemeijer A, et al. Translocation of $\mathrm{c}$-ab1 oncogene correlates with the presence of a Philadelphia chromosome in chronic myelocytic leukaemia. Nature 1983; 306: 277-80.

4. Jabbour EJ, Faderl S, Kantarjian HM. Adult acute lymphoblastic leukemia. Mayo Clin Proc 2005; 80: 1517-27.

5. Usvasalo A, Räty R, Harila-Saari A, et al. Acute lymphoblastic leukemias with normal karyotypes are not without genomic aberrations. Cancer Genet Cytogenet 2009; 192: 10-7.

6. Pui CH, Relling MV, Downing JR, Acute lymphoblastic leukemia. N Engl J Med 2004; 350: 1535-48.

7. Rowley JD. The critical role of chromosome translocations in human leukemias. Annu Rev Genet 1998; 32: 495-519.

8. Armstrong SA, Look AT. Molecular genetics of acutelymphoblastic leukemia. J Clin Oncol 2005; 23: 6306-15.

9. Wiemels JL, Cazzaniga G, Daniotti M, et al. Prenatal origin of acute lymphoblastic leukaemia in children. Lancet 1999; 354: 1499-503.

10. Roberts KG, Mullighan CG. Genomics in acute lymphoblastic leukaemia: insights and treatment implications. Nat Rev Clin Oncol 2015; 12: 344- 57.

11. Bacher U, Kohlmann A, Haferlach T. Gene expression profiling for diagnosis and therapy in acute leukaemia and other haematologic malignancies. Cancer Treat Rev 2010; 36: 637-46.

12. Bungaro S, Dell'Orto MC, Zangrando A, et al. Integration of genomic and gene expression data of childhood ALL with- out known aberrations identifies subgroups with specific genetic hallmarks. Genes Chromosomes Cancer 2009; 48: 22-38.

13. Iacobucci I, Mullighan C. Genetic basis of acute lymphoblastic leukemia. J Clin Oncol 2017; 35: 975-83. 
14. Arber D, Orazi A, Hasserjian R, et al. The 2016 revision to the World Health Organization classification of myeloid neoplasms and acute leukemia. Blood 2016; 127: 2391-405

15. Wetzler M, Dodge RK, Mrozek K, et al. Prospective karyotype analysis in adult acute lymphoblastic leukemia: the cancer and leukemia Group B experience. Blood 1999; 93: 3983-93.

16. Faderl S, Jeha S, Kantarjian HM. The biology and therapy of adult acute lymphoblastic leukemia. Cancer 2003; 98: 1337-54.

17. Burmeister T, Schwartz S, Bartram CR, Gokbuget N, Hoelzer $\mathrm{D}$, Thiel E. Patients' age and BCR-ABL frequency in adult B-precursor ALL: a retrospective analysis from the GMALL study group. Blood 2008; 112: 918-9.

18. Secker-Walker LM, Craig JM, Hawkins JM, Hoffbrand AV Philadelphia positive acute lymphoblastic leukemia in adults: age distribution, BCR breakpoint and prognostic significance. Leukemia 1991; 5: 196-9.

19. Pui CH, Evans WE. Treatment of acute lymphoblastic leukemia. N Engl J Med 2006; 354: 166-78.

20. Downing JR, Shannon KM. Acute leukemia: a pediatric perspective. Cancer Cell 2002; 2: p.437-45.

21. Rowley JD. Letter: a new consistent chromosomal abnormality in chronic myelogenous leukaemia identified by quinacrine fluorescence and Giemsa staining. Nature 1973; 243: 290-3.

22. Teitell MA, Pandolfi PP. Molecular genetics of acute lymphoblastic leukemia. Annu Rev Pathol 2009; 4: 175-98.

23. Nashed AL, Rao KW, Gulley ML. Clinical applications of BCRABL molecular testing in acute leukemia. J Mol Diagn 2003; 5 63-72.

24. Gleissner B, Gokbuget N, Bartram CR, et al. Leading prognostic relevance of the BCR-ABL translocation in adult acute B-lineage lymphoblastic leukemia: a prospective study of the German Multicenter Trial Group and confirmed polymerase chain reaction analysis. Blood 2002; 99: 1536-43.

25. Vitale A, Guarini A, Chiaretti S, Foa R. The changing scene of adult acute lymphoblastic leukemia. Curr Opin Oncol 2006; 18: 652-9.

26. Jaso J, Thomas DA, Cunningham K, et al. Prognostic significance of immunophenotypic and karyotypic features of Philadelphia positive b-lymphoblastic leukemia in the era of tyrosine kinase inhibitors. Cancer 2011; 117: 4009-17

27. Linabery AM, Ross JA. Trends in childhood cancer incidence in the U.S. Cancer 2008; 112: 416-32.

28. Bassan R, Hoelzer D. Modern therapy of acute lymphoblastic leukemia. J Clin Oncol 2011; 29: 532-43.

29. Mullighan CG. New strategies in acute lymphoblastic leukemia translating advances in genomics into clinical practice. Clin Cancer Res 2011; 17: 396-400.

30. Nowell PC, Hungerford DA. Chromosome studies on normal and leukemic human leukocytes. J Natl Cancer Inst 1960; 25: 85-109.

31. Ravandi F. How I treat Philadelphia chromosome-positive acute lymphoblastic leukemia. Blood 2019; 133: 130-6. (doi: 10.1182/ blood-2018-08-832105).

32. de França Azevedo I, da Silva Júnior RM, de Vasconcelos AV, et al. Frequency of p190 and p210 BCR-ABL rearrangements and survival in Brazilian adult patients with acute lymphoblastic leukemia. Rev Bras Hematol Hemoter 2014; 36: 351-5.

33. Dombret H, Gabert J, Boiron JM, et al. Outcome of treatment in adults with Philadelphia chromosome-positive acute lymphoblastic leukemia results of the prospective multicenter LALA-94 trial. Blood 2002; 100: 2357-66. 